\title{
Anglo-Indian Novels and the Politics of Canon-Formation: Tara as a Case Study
}

\author{
Ayusman Chakraborty \\ Taki Government College, West Bengal, India
}

Received October 26, 2016; Revised December 20, 2016; Accepted December 25, 2016; Published January 14, 2017

\begin{abstract}
This article studies the reception of a popular $19^{\text {th }}$ century Anglo-Indian novel, Captain Philip Meadows Taylor's Tara (1863). This novel was once assigned a central position in the canon of Anglo-Indian novel. However, in the present age, it has been displaced from its position of eminence. This article contends that the present marginalization of Tara can be related to the change in the political and ideological orientation of readers. The ideological position of contemporary readers and critics make them approach colonial texts with a different mindset than their predecessors. This in turn affects the canon, modifying and altering it in the process. The present marginalization of Tara highlights how the changes in politics and practice of reading affect the canon formation of Anglo-Indian novels.
\end{abstract}

Key words: Anglo-Indian novel, canon-formation, Philip Meadows Taylor, Tara.

\section{Introduction}

Anglo-Indian novel forms a minor but significant branch of British colonial literature on India. Originating in 1785 with the anonymously published The Disinterested Nabob, it continued to exist till the late twentieth century. This article examines how the changes in the political and ideological orientations of successive generations of readers affect the canon-formation of AngloIndian novels. To do this, it makes a case study of Captain Philip Meadows Taylor's Tara, which was once regarded as a canonical Anglo-Indian novel but which has now been dethroned from its position of eminence and almost forgotten.

This article is divided into two sections. The first section focuses on the canon-formation of Anglo-Indian novels. It shows how the canon is modified vis-à-vis the changes in political and ideological orientation of readers. The second section studies the reception of Tara in succeeding ages. Through this it attempts to demonstrate that the present marginalization of this novel is the direct outcome of contemporary post-colonial politics and practice of reading.

\section{The Formation of the Canon of Anglo-Indian Novel: A Review}

Anglo-Indian literature originated in the colony, and, hence, was never considered a part of mainstream British literature. Not being so well known, it requires a brief introduction. Today the

(c) AesthetixMS 2016. This Open Access article is published under a Creative Commons Attribution Non-Commercial 4.0 International License (http://creativecommons.org/licenses/by-nc/4.o/), which permits non-commercial re-use, distribution, and reproduction in any medium, provided the original work is properly cited. For citation use the DOI. For commercial re-use, please contact editor@rupkatha.com. 
word "Anglo-Indian" has come to mean those Indian citizens one of whose ancestors from the male line was a European by birth. Anglo-Indian literature, in this sense, refers to the literature created by the people of mixed Indo-European descent. However, in the nineteenth and the early twentieth century the word "Anglo-Indian" had a completely different meaning. At that time, this word was used by the British community residing in India to describe themselves, while "Eurasian" was the word used by them to describe the people of so called mixed racial descent. Anglo-Indian literature is the literature of these British expatriates, and, as such, a branch of British colonial literature on India. Living in proximity to the colonial contact zone, the AngloIndian authors of that time possessed direct first-hand knowledge of India. As a result, their works tended to be more realistic, albeit more insipid, than the fanciful creations of the metropolitan authors. Anglo-Indian literature enjoyed its golden age during the first three decades of the twentieth century, but expired soon after with the independence of India in 1947. While British expatriates continue to write on India, the particular colonial relations which influenced and shaped Anglo-Indian literature is now gone forever.

As a sub-genre of Anglo-Indian literature, Anglo-Indian novel was never popular beyond a small circle. It failed to draw the attention of the major reading public in both Britain and India. Two factors were mainly responsible for its lack of success in Britain. First, barring the works of a few authors like Rudyard Kipling, George Orwell and E. M. Forster, the productions of the majority of Anglo-Indian novelists were of aesthetically poor quality. Commenting on AngloIndian novels, Susanne Howe states, "Novels about India provide more vicarious discomfort than anyone is entitled to. They are among the unhappiest books in the language." (Howe 1949, 32) Oaten explains the reason behind this by pointing out that the Anglo-Indian novelists either wrote too much or too little. They either "retarded the story with voluminous explanations" thinking that their readers knew too little about India, or they explained too little making their novels hard to understand. (Oaten 1908, 142) Thus the British readers found it difficult to appreciate their works. Secondly, it has been alleged that the ordinary British readers were too insular in their feelings to interest themselves in matters outside 'home'. The reviewer of Tara for the Calcutta Review observes, "... it is extremely hard to interest English people in characters and modes of life so different from our own. We are insular in our feelings." (Review 1864, 193) Oaten too admits that "Anglo-Indian writers have been greatly handicapped by the lack of interest of English people in things Indian ..." (Oaten 1908, 46) One can take these writers at their word, because they were themselves Englishmen and were thus well acquainted with the temperament of the ordinary British readers. As for the Indians, the ordinary readers found it difficult to enjoy these novels for several reasons. In most of these novels, the Indians were presented in a very harsh light. These novels thus easily antagonized the Indians. Moreover, the appeal of the exotic, with which the Anglo-Indian novelists tried to allure the British readers, failed to attract the Indians. The descriptions of Indian life and manners were not only commonplace and banal to the Indians, but there were also gross inaccuracies in the presentation of these details. In his article "On the Ignorance of the Learned British: An Aspect of Anglo-Indian Fiction", M. K. Naik discusses the errors of the Anglo-Indian novelists at length. He concludes, "whether it is Indian geography or history or politics, religion, culture, or society or character, the Anglo-Indian novelists' presentation, upon close scrutiny, seems to be by and large shocking, inadequate, flawed and distorted in a number of ways." (Naik 1991, 89) Given these facts, it is not surprising that the Indian readers failed to appreciate these novels. Interestingly, there was a marked decline in the study of Anglo-Indian novels in the years following the independence of India. It remains to be empirically proved that this was the natural outcome of the decolonization process, though there seems to be a high probability that it was so. Evidently, the newly liberated Indians were 
unwilling to accept this humiliating legacy of colonialism. Shunned by both British and Indian readers, Anglo-Indian novels thus passed into relative obscurity in the post-independence period.

The interest in Anglo-Indian novels began to revive only after the 1980s. When one speaks of 'interest', one obviously means the interest of the critics, as the common readers continue to avoid Anglo-Indian literature even in the present day. While Allen J. Greenberger's The British Image of India is the only significant work belonging to the pre-1980 period, several important studies on Anglo-Indian novels were published in the post-1980 era. B. J. Moore-Gilbert's Kipling and "Orientalism" (1986), Udayon Misra's The Raj in Fiction (1987), Rashna B. Singh's The Imperishable Empire (1988), and Amal Chatterjee's Representations of India, 1740 - 1840 (1998) are some such works. One may note that the revival of interest in Anglo-Indian literature as a whole coincided with the publication of Edward Said's Orientalism in 1978. Doubtlessly, the new methodology and insight provided by Said encouraged and influenced the scholars studying Anglo-Indian literature. It is to be kept in mind that all the works published after 1980 draw heavily on the writings of colonial discourse analysts. A new trend was set, which continues unchallenged even in the twenty first century.

With the revival of interest in Anglo-Indian novels in the 1980s, there arose the need to redefine the canon. This was mainly due to the passing away of the old standards of judgment. Imbued with postcolonial sensibilities, the contemporary critics of Anglo-Indian novels studied these texts with a different mindset than their predecessors. In this context, it would be relevant to consider the approach of the older critics towards Anglo-Indian novels. The task of shaping the canon was begun in the early twentieth century by the Anglo-Indians themselves. In the "Appendix" to his book A Sketch of Anglo-Indian Literature (1908), Edward Farley Oaten first provided a catalogue of Anglo-Indian novels. Prepared as it was before 1908, this list was bound to remain incomplete. After Oaten, Robert Sencourt paid some attention to Anglo-Indian novel in his book India in English Fiction (1923). But, as the very title of the book suggests, the work was much wider in scope and could not do sufficient justice to Anglo-Indian novels. In his article "The Anglo-Indian Novelist” Sir Alfred Comyn Lyall studies several popular nineteenth century AngloIndian novels. There were also some Indian scholars writing at that time who contributed towards Anglo-Indian canon-formation. Kiran Nath Dhar provides a catalogue of major Anglo-Indian novels in his article "Some Indian Novels" published in the Calcutta Review in 1908. Bhupal Singh's A Survey of Anglo-Indian Fiction (1934) is another significant work on Anglo-Indian novels and short stories. All these critics based their evaluations on a common standard of judgment. While the influence of the dominant liberal humanist ideology urged them to take aesthetic considerations into account, they also judged a writer on the basis of his accuracy in depicting life in India. By 'life in India' these scholars meant both the life of the British expatriates as well as that of the natives. The Anglo-Indian novelists were expected to familiarize the British readers with the unknown aspects of 'Indian life'. It is to be kept in mind that a significant number of these critics were themselves British. Anglo-Indian novels provided them with a gateway to the unknown. Accordingly, Anglo-Indian novels were valued as much for their informativeness as for the enjoyment they provided. Even the Indian critics of that period did not demur at the norms laid down by the British critics. They acknowledged the interpretive function of Anglo-Indian novels, viewing them as bridges between the East and the West.

Following the rise of post colonialism as a discipline in the mid twentieth century there was a change in the critical standards. Hitherto, most critics of Anglo-Indian novels were liberal humanists in their outlook. They mainly rated a text on the basis of its literary merit, given due importance to the elements of form and style. They also valued an Anglo-Indian novel for the 
information it conveyed. The late twentieth century critics, on the other hand, became professedly ant-colonial in politics. They no longer concerned themselves with questions about factualism and verisimilitude as previous critics had done. Nor did they consider the literary merit of a work. To them Anglo-Indian texts were valuable only as historical and social documents. Study of Anglo-Indian literature was deemed important as it was found to reveal the workings of British colonialism. Influenced by Michel Foucault and Edward Said, these critics began to study how colonial novels constructed a particular knowledge of India, a knowledge that was shaped by colonial power. They no longer concerned themselves with the truth value of a work, as earlier writers had done. Being consciously 'postcolonial', they used these novels to criticize British colonialism and imperialism. Anglo-Indian novels, therefore, were ceased to be considered as works of art. Allen J. Greenberger describes how these texts became "valuable evidence for the historian" during this time. He points out that Anglo-Indian novels provided one with necessary insight into Britain's relationship with India. (Greenberger 1969, 1) Frances M. Mannsaker too shows how early twentieth century Anglo-Indian novels became indispensable to historians and post-colonial critics:

But they are important for more than their very limited literary interest. With a few exceptions, they are based on the conventions and assumptions of the society from which they sprang. They tell us a great deal about the racial attitudes of ordinary AngloIndian officials at the end of the nineteenth century, and they give some very suggestive hints for the historian about the limitations of the Anglo-Indian rule in India ... (Mannsaker 1980, 33-34)

This change in reading practice inevitably brought about the transformation of the canon. In the field of the novel, specifically, the change was sweeping. Many canonical novels were now consigned to oblivion, while many less known works were either rediscovered or reinstated to eminence.

From the examination of the contemporary trend in criticism, it becomes apparent that the scholars of the present generation treat Anglo-Indian novels simply as colonial texts rather than as works of art. Such texts are deemed important as they are believed to highlight the workings of colonialism. Naturally these readers are not interested in those Anglo-Indian novels which do not focus on Indo-British relationship. As a result, such novels have been marginalized in the present times. The typical example is Tara, which was once recognized as Taylor's masterpiece, but which has been largely forgotten today. The following section traces the reception of the novel from its very origin to the present day, and shows how the post-colonial practice of reading has deprived this text of the dominant position it once enjoyed.

\section{The Reception of Tara: From its Origin to the Present}

Captain Philip Meadows Taylor wrote six novels - Confessions of a Thug, Tippoo Sultaun, Tara, Ralph Darnell, Seeta, and A Noble Queen. Tara, his third novel, was published in 1863. Taylor began working on this novel in 1841, but he left it midway and completed it only in 1862 . This long gestation period of almost twenty years ultimately worked to his advantage. David Finkelstein points out that it gave Taylor the much-desired opportunity to carefully plan the plot. (Finkelstein 1990, 95) It is certain that of all his works, it is Tara that appears most artistically crafted.

Like all other works of Taylor except Confessions of a Thug, Tara is a historical romance. The novel is set in Deccan India in 1657. It describes the rise of the Marathas under Shivaji and the execution of Afzal Khan by him. The eponymous heroine Tara is the daughter of the Brahmin 
Vyas Shastree. She is a virgin widow. To escape the humiliations of widowhood, she becomes a priestess at the temple of Tulja Bhabani. Morro Trimmul, a corrupt Brahmin who serves Shivaji as a spy, becomes her admirer. He makes overtures to Tara which she rejects with scorn. Enraged, Trimmul kidnaps Tara while Tuljapur is raided by Afzal Khan's force. However, she is rescued by Fazil, the son of Afzal Khan. Believing that her parents had perished during the raid, Tara accompanies Afzal and his family. Despite their religious differences, she and Fazil fall in love. However, the Hindus soon reclaim her and she is placed in the care of a Brahmin. By this time, Afzal is killed by Shivaji and his army is entirely routed. Once again threatened by Trimmul, Tara decides to become a sati to save her honour. Fazil rescues her at the very last moment from the funeral pyre and carries her off. Moro Trimmul, who tries to stop him, is killed in the fray. Tara converts to Islam and the novel ends with the marriage of Tara and Fazil.

Tara was published by William Blackwood and Sons in October 1863. David Finkelstein informs that the initial sale of Tara was not at all encouraging. The work sold moderately, though several publishers later reprinted it. (Finkelstein 1990, 21- 22) It is clear that in the beginning the ordinary British readers failed to appreciate the novel on account of its unfamiliar setting and content. So far as critical judgment is concerned, however, the work was deemed a success. It was favourably reviewed in most of the major British newspapers and journals of that time. What the reviewers admired was Taylor's eye for details. They felt that he had adequately familiarized the unknown aspects of Indian life to the reading public in Britain. The reviewer of the novel for The Spectator points out that though "the difficulty of telling an Asiatic story is almost insuperable", Taylor has faced it courageously and "if he has not overcome it, he has produced a very remarkable book". (Review 1863, 2634) Margaret Oliphant, the reviewer the novel for the Blackwood's Edinburgh Magazine, lavishly praises Taylor for presenting an "insider's picture" of native life. She writes:

From the outside we have looked at the temple and mosque and bazaar and palace, and found them repulsive enough. Soldiers, who were contemptuous of the race, and priests who looked not only with Christian repugnance but professional horror at its complicated idolatries, have been our chief informants on the subject. Now here is a different aspect of the picture. It is from within, from the centre of the quaint domestic circle, from the altar of the deity, from the familiar life of what would be devout households and pious worshippers, could they, by any stretching of the word, be concluded Christians, that we are called upon to look. (Oliphant 1863, 626)

Oliphant feels that Taylor could write as he did only because he possessed the rare gifts of objectivity and detachment. She declares, "In short, he has clearly preferred to consider them from their own point of view rather than the half-contemptuous, half-pathetic contemplation which is natural to the ordinary English spectator." (Oliphant 1863, 627) This, of course, is an exaggeration. Taylor was a man of his times and could not overcome common prejudices. His hostile representation of Shivaji in this novel definitely proves this. However, it is true that he was free from the snobbery that characterized most other Anglo-Indian authors. Even his detractors had to admit that he did not (consciously) look down upon native life. As a result, he was able to portray it almost accurately. The reviewer of Tara for The Calcutta Review correctly observes, "It is the most successful novel of native life that has ever been published." (Review 1864, 193)

From the comments of these early reviewers it becomes clear that Tara was admired in the nineteenth century as an accurate picture of Indian life. The early twentieth century critics of Anglo-Indian literature, who looked for factualism more than anything else, were therefore fascinated by it. Of all the novels of Taylor, Alfred Comyn Lyall focuses only on Tara showing that 
he liked it the most. He not only lauds it as an accurate picture of native life but also praises it because, "It was for a long time the only Indian novel in which the 'dramatis personae' are entirely native." (Lyall 1915, n.p.) It was T. O. D. Dunn who first called it Taylor's masterpiece. He believed that "Tara is the largest and most ambitious of all Meadows Taylor's works, and upon it his reputation as a novelist must rest." (Dunn 1918, 26) Many other critics of this period also shared this view. Gobind Singh Mansukhani, who published the first full length study on Taylor, asserts, "Undoubtedly Tara is the author's best work; it has neither the monotony nor the looseness of Confessions nor the blood and fury of Tippoo Sultaun; it is rich in the stuff of human life ..." (Mansukhani 1951, 148) Professor Kavya Viswanatham, another critic to single out Tara for study, asserts, "Of all his novels, 'Tara' is said to be the best. It is." (Viswanatham 1971, 37) Even critics like Bhupal Singh and Udayon Misra, who do not hail it as his masterpiece, consider it to be superior to his most other novels. Bhupal Singh states, "In Tara Meadows Taylor is at the height of his powers. Ralph Darnell and Seeta show signs of exhaustion." He further argues, "Seeta is inferior to Tara in breadth of canvas as well as in general consistency and vigour of conception." (Singh 1934, 50) Udayon Misra echoes him saying, "Ralph Darnell and Seeta do not reach the standard attained by Tara, which is decidedly the best expression of Taylor's creative power." He admires the novel "for its excellence of detail, well-executed plot and subtle characterization." (Misra 1987, 81) Misra further contends that the novel preaches Hindu Muslim unity, a view which he shares with Viswanatham. This was against the general trend of Anglo-Indian novels which compartmentalized the Hindus and the Muslims into two mutually antagonistic camps. Both Misra and Viswanatham feel that it was Taylor's acute insight into Indian life that enabled him to accurately portray the prevailing social reality. Here one may note how the self-awareness of these writers as 'Indian critics' affect their reading of the novel. Committed to the ideals of secularism and liberalism, they highlight those features of the novel that support their ideological position. The observations of these critics make it clear that all of them assigned a central position to Tara in the canon of the Anglo-Indian novel.

Tara suffered a reversal of fortune with the change in critical standards. Ironically, the same absence of European characters, that failed to attract the ordinary (British) readers once, now again worked to its disadvantage. The contemporary critics, who study Anglo-Indian texts to analyse colonial discourse on India, fail to draw anything substantial from Tara. The novel neither portrays the relationship between the colonizers and the colonized nor represents the Indians with apparent hostility. In its place, they prefer Confessions of a Thug and Seeta which allow easy theorization on colonial experience. It is interesting that Seeta, which was once marginalized, has been revived by post-colonial criticism, whereas Tara, which was a canonical novel once, has been marginalized today.

The exclusion of Tara from the canon becomes clear once we undertake a survey of the modern critical writings on Taylor's works. It immediately transpires that Confessions of a Thug has become the most favoured text today. Between 1980 and 2015, the novel was considered in as many as fifteen studies. Besides G. S. Manuskhani, M. Sarada and David Finkelstein, who have conducted full-fledged research on Taylor's novels, eminent scholars like Patrick Brantlinger, B. J. Moore-Gilbert, Jyotsna G. Singh, Rashna B. Singh, Parama Roy, Amal Chatterjee, Pablo Upamanyu Mukherjee, Caroline Reitz and Alex Tickell have written on it. Scholars studying British representations of Thuggee like Kim A. Wagner and Martine Van Woerkens also find this novel useful. Besides these, as many as four full length articles have been published on Confessions of a Thug. These include Robert Grant William's "Shadows of Imperialism: Canonical Typology in Taylor's Confessions of a Thug”, Javed Majeed's "Meadows Taylor's Confessions of a Thug: the Anglo-Indian Novel as a Genre in the Making", Mary Poovey's "Ambiguity and Historicism: 
Interpreting 'Confessions of a Thug”, and Matthew Kaiser's "Facing a Mirror: Philip Meadows Taylor's Confessions of a Thug and the Politics of Imperial Self-Incrimination." It has been felt that the novel not only highlights Thuggee but also problematizes British representation of it. As a matter of fact, scholars have grouped themselves into two opposing camps, arguing whether the novel is pro- or anti-Thuggee in intention. It has been suggested that Taylor's sympathetic portrayal of the Thug cum protagonist Ameer Ali complicates traditional negative representation of Thuggee. This debate centring the novel has helped to popularize it in the recent times.

Seeta is the next favourite of contemporary scholars, having been considered in ten studies conducted between 1980 and 2015. Given that it was once considered as an inferior work, the revival of interest in it appears all the more striking. Scholars theorizing on British representation of the Mutiny, such as Gautam Chakravarty, Jennifer H. Pauley-Gose, Upamanyu Pablo Mukherjee and Patrick Brantlinger, study this novel as a key text. As with Confessions of a Thug, this novel is believed to subtly challenge the traditional British understanding of the Mutiny. It sympathizes with the Rani of Jhansi, who is shown to have harboured genuine grievances. Though Taylor calls her "a vindictive murderess" following the tradition of Mutiny narratives, he also hints that the British have unjustly deprived her of her kingdom. (Taylor 1872, 252) Contemporary readers also allege that the novel covertly sympathizes with the rebellious Sepoys, though this is a contentious issue. The novel is also considered by those scholars who focus on colonial construction of Indian women. The studies of Shuchi Kapila, Indrani Sen, Sangeeta Ray, and Nancy L. Paxton belong to this group. The novel depicts the successful interracial marriage between the Indian heroine Seeta and the British officer Cyril Brandon. Naturally those critics who study British representation of interracial marriage and miscegenation find this novel useful.

It appears that Tara has lost as much popularity in recent years as Seeta has gained. As noted earlier, it was once the favourite novel of critics. Modern scholars have, however, lost interest in it. Tara finds mention in only five studies conducted between 1980 and 2015. These are by Finkelstein, Sarada, Paxton, Sen, and Misra. The studies of Sen and Paxton focus on colonial representation of Indian women. The rest concentrate on the general features of the novel. As the novel portrays a pre-colonial past, the modern critics find it insipid. The rest of Taylor's works fare even worse. Besides Mansukhani, Finkelstein and Sarada, only Sen and Misra study Ralph Darnell. A Noble Queen is considered in even fewer works. From this brief survey of contemporary critical writings on Taylor it becomes apparent that Tara is considered less important today than it was before. Clearly, the present low-keyed appeal of the novel portends its gradual displacement from the Anglo-Indian canon.

\section{Conclusion}

Our survey of existing literature shows that Tara is being gradually ousted from the canon of Anglo-Indian novels. The present marginalization of this novel provides us with an insight into the process of Anglo-Indian canon formation. It is well recognized that the boundary of literary canon remains ever indefinite. Often works which were once on the fringe of the canon get transferred to a position of eminence. The typical case is that of Seeta which has been revived by contemporary scholars. On the other hand, works that were once canonical may lose their relevance in a later period. Tara is a work of this sort. During the colonial period, it was praised both for its literary merit and for the information on India that it provided. The British readers of that time were charmed by the exotic content of the novel. Hence they assigned it a central position in the canon of Anglo-Indian novel. The situation however changed with the 
independence of India. Having lost their colony, the British became disinterested in India. The 'Indian life' that the novel professed to describe also changed in nature with the passage of time. As a result, the novel could not convey any meaningful experience to its modern readers. Hence, it lost its relevance in the present age.

There is little doubt that the fate of Tara would have been different if the novel reflected colonial experience. Today, Anglo-Indian novels are valued mainly as historical documents that highlight the operations of British colonialism. Approaching these novels with postcolonial sensibility, the modern scholars study how these novels portray the power relations between the colonizers and the colonized. Tara, with its purely Indian cast, fails to gratify these scholars. On the other hand, Confessions of a Thug and Seeta are valued for the insight they provide. Therefore, it is not surprising that these novels have eclipsed the popularity of Tara.

Anglo-Indian literature has become today the relic of a bygone age. Contemporary readers cannot approach Anglo-Indian novels with the same mindset as their predecessors. It is natural that their expectations and preferences would be different. This in turn affects Anglo-Indian canon-formation as this article demonstrates.

\section{Acknowledgment}

I am indebted to the Edinburgh University Library for providing me access to the unpublished doctoral thesis of Dr David Finkelstein.

\section{References}

\section{Published Works}

Dhar, Kiran Nath. (1908, October). Some Indian Novels. Calcutta Review, CCLIV, 561 - 583.

Dunn, T. O. D. (1918, January). Meadows Taylor: His Autobiography and Novels. Calcutta Review, 291, 1 - 29.

Greenberger, Allen J. (1969). The British Image of India. London: Oxford University Press.

Howe, Susanne. (1949). Novels of Empire. New York: Columbia University Press.

Kaiser, Matthew. (2009). "Facing a Mirror: Philip Meadows Taylor's Confessions of a Thug and the Politics of Imperial Self-Incrimination”. In Stones of Law, Bricks of Shame. (Eds.) Jan Alber and Frank Lauterbach. Toronto: University of Toronto Press.

Lyall, Alfred Comyn. (1915). "The Anglo-Indian Novelist”. In Studies in Literature and History. London: John Murray. https://ia600504.us.archive.org/17/items/studiesinliterat25937gut/25937-8.txt.

Majeed, Javed. (1996). “"Meadows Taylor's Confessions of a Thug: the Anglo-Indian Novel as a Genre in the Making”. In Writing India 1757 - 1990. (Ed.) Bart Moor-Gilbert. Manchester: Manchester University Press.

Mannsaker, Frances M. (1980, Autumn). East and West: Anglo-Indian Racial Attitudes as Reflected in Popular Fiction, 1890 - 1914. Victorian Studies, 24 (1), 33 - 51.

Mansukhani, Gobind Singh. (1951). Philip Meadows Taylor: A Critical Study. Bombay: New Book Co. Ltd.

Misra, Udayon. (1987). The Raj in Fiction. Delhi: B. R. Publishing Corporation.

Naik, M. K. (1991, September-October). On the Ignorance of the Learned British: An Aspect of Anglo-Indian Fiction. Indian Literature, 34 (5), 75 - 93. 
Oaten, Edward Farley. (1908). A Sketch of Anglo-Indian Literature. London: Kegan Paul Trench Trübner \& Co. Ltd.

Oliphant, Margaret. (1863, November). Review of Tara, by Philip Meadows Taylor. Blackwood's Edinburgh Magazine, 94:577, 624-634.

Poovey, Mary. (2004, January). Ambiguity and Historicism: Interpreting “Confessions of a Thug”. Narrative $12(1), 3-21$.

Review of Tara, By Philip Meadows Taylor. (1864, January). Calcutta Review, 39:77, 193-198.

Review of Tara, By Philip Meadows Taylor. (1864, January). The Spectator, 36: 1842, 2634.

Sarada, M. (1995). Anglo-Indian Novel: Philip Meadows Taylor. Delhi: B. R. Publishing Corporation.

Sencourt, Robert. (1923). India in English Literature. Port Washington: Kennikat Press.

Singh, Bhupal. (1934). A Survey of Anglo-Indian Fiction. London: Oxford University Press.

Taylor, Philip Meadows. (1863). Tara: A Mahratta Tale. 3 Vols. Edinburgh: William Blackwood and Sons.

Taylor, Philip Meadows. (1872). Seeta. Vol. 3. London: Henry S King \& Co.

Viswanatham, K. (1971). India in English Fiction. Waltair: Andhra University Press.

Williams, Robert Grant. (1992-93, Winter). Shadows of Imperialism: Canonical Typology in Taylor's Confessions of a Thug. Dalhousie Review. $482-493$.

\section{Unpublished Materials:}

Finkelstein, David. (1990). "A Study of the Works of Philip Meadows Taylor". PhD diss: Edinburgh University.

Dr Ayusman Chakraborty has conducted his doctoral research from Jadavpur University. He is working as Assistant Professor of English (W. B. E. S), and is currently posted at Taki Government College. He is interested in nineteenth century British colonial literature on India, and has written several articles on the subject. 